\title{
Mechanical properties of lithic raw materials from Kazakhstan: comparing chert, shale, and porphyry
}

\author{
Abay Namen ${ }^{1,2}$, Radu Iovita ${ }^{1,7}$, Klaus G. Nickel ${ }^{3,4}$, Aristeidis Varis ${ }^{1,5}$, Zhaken \\ Taimagambetov $^{2,6}$, Patrick Schmidt ${ }^{1,3}$ \\ ${ }^{1}$ Department of Early Prehistory and Quaternary Ecology, University of Tübingen, Tübingen \\ 72070, Germany
}

${ }^{2}$ Department of Archaeology, Ethnology and Museology, Faculty of History, Archaeology and Ethnology, Al Farabi Kazakh National University, Almaty 050040, Kazakhstan

${ }^{3}$ Department of Geosciences, Applied Mineralogy, Eberhard Karls University of Tübingen, Tübingen 72070, Germany

${ }^{4}$ Competence Center Archaeometry - Baden-Württemberg, Eberhard Karls University of Tübingen, Wilhelmstraße 56, Tübingen 72074, Germany

${ }^{5}$ Institute of Archaeological Sciences, Eberhard Karls University of Tübingen, Tübingen 72070, Germany

${ }^{6}$ National Museum of the Republic of Kazakhstan, Nur-Sultan 010000, Kazakhstan

${ }^{7}$ Center for the Study of Human Origins, Department of Anthropology, New York University, New York 10003, USA

\section{Abstract}

The study of lithic raw material quality has become one of the major interpretive tools to investigate the raw material selection behaviour and its influence to the knapping technology. In order to make objective assessments of raw material quality, their mechanical properties (e.g., fracture resistance, hardness, modulus of elasticity) should be measured. However, such comprehensive investigations are lacking for the Palaeolithic of Kazakhstan. In this work, we investigate geological and archaeological lithic raw material samples of chert, porphyry, and shale collected from the Inner Asian Mountain Corridor (henceforth IAMC). Selected samples of aforementioned rocks were tested by means of Vickers and Knoop indentation methods to determine one aspect of their mechanical properties: their indentation fracture resistance (a value closely related to fracture toughness). These tests were complemented by traditional petrographic studies to characterise the mineralogical composition and evaluate the level of impurities that could have potentially affected the mechanical properties. The results show that materials, such as porphyry, previously thought to be of lower quality due to the anisotropic composition and coarse feldspar and quartz phenocrysts embedded in a silica rich matrix, possess fracture toughness values that can be compared to those of chert. Thus, it appears that different raw materials cannot be distinguished from the point of view of indentation fracture resistance, calling for detailed supplementary analyses of different fracture properties. This work also offers first insight into the quality of archaeological porphyry that was utilised as a primary raw material at various Middle and Upper Palaeolithic sites in the IAMC.

Key words: Palaeolithic; mechanical properties; elasticity; hardness; fracture resistance. 


\section{Introduction}

In recent years, the study of differences of lithic raw materials for the production of stone tools has received much attention because different types of rocks selected to produce lithics influence the technology and type of tools manufactured (Andrefsky, 1994; Brantingham et al., 2000; Kuhn, 2004; Braun et al., 2009; Kot et al., 2020; Shimelmitz et al., 2020). It also helps to understand the way in which rock attributes affect reduction sequences and edge-wear properties of tools (Brantingham et al., 2000; Braun et al., 2009; Goldman-Neuman and Hovers, 2012). Sedimentary rocks such as chert, flint, silicified shale, and other silica rich rocks were commonly used due to their predictable fracturing properties and good knapping qualities. Raw material quality is commonly related with the mineralogical structure (e.g., grain size and shape) and purity of a given material. In most cases, raw materials that have isotropic mechanical properties are often considered to be of higher quality for tool making. Microstructural characteristics are also thought to potentially affect the size and/or shape of a final knapped product (Brantingham et al., 2000). This is supported by replicative experiments conducted by contemporary knappers which have demonstrated that higher quality raw material has a direct influence on the manufacturing process (Crabtree, 1967; Cotterell et al., 1985; Cotterell and Kamminga, 1987; Collins, 2008; Manninen, 2016; Dogandžić et al., 2020; Marreiros et al., 2020; McPherron et al., 2020).

Some scholars argue that a good raw material that is suitable for knapping should be brittle, elastic, and isotropic (Cotterell et al., 1985; Cotterell and Kamminga, 1987). In the past, only few semi-quantitative and quantitative studies of the mechanical properties have been carried out, and these date to the mid-20 ${ }^{\text {th }}$ century. Goodman's (1944) experimental studies on this subject have been one of the first to study the hardness, toughness, and density of archaeological stone tools. Every stone tool can be seen as a unique material that has different raw material structure, morphology, and composition. The study by Moník and Hadraba (2016), attempted to answer the question of whether differences in raw material procurement may have been driven by the mechanical properties of selected materials or not. Studies conducted by Lerner et al. (2007) suggest that the physical properties of lithic raw materials have direct implications for use-wear accrual rates, meaning that roughness is linked to the rate of wear on stone tools. However, similar works in mechanical characterization of raw materials from archaeological contexts are found in limited quantities. Some of the available studies concern mineralogical, chemical and crystallographic transformations (Schmidt and Fröhlich, 2011), as well as few detailed studies were dedicated to determine the thermal evolution of fracture mechanics (Domanski et al., 1994; Domanski and Webb, 2007; Schmidt et al., 2017; 2019). The importance of the studies of mechanical properties become more pronounced due to the growing body of evidence that indicates deliberate alteration of lithic raw material properties by hominins to increase the knapping qualities of rocks which has implications for the evolution of human cognition (Domanski et al., 1994; Schmidt et al., 2017; 2019; Mraz et al., 2019; Schmidt, 2020; Moník et al., 2021).

The current work is based on a systematic investigation of archaeological stone tools and geological samples of raw materials to determine the mechanical properties from different Upper Palaeolithic sites of Kazakhstan (Fig. 1). The primary objectives are (1) to test geological and archaeological samples to determine their mechanical properties, and (2) to preliminarily assess how these properties affect the knapping technology. Previous studies have been primarily concentrated on silica materials such as chert and silcrete (Domanski et al., 1994; Lerner et al., 2007; Schmidt et al., 2019), but other types of sedimentary and volcanic rocks found in archaeological contexts have received less attention. Here, we attempt to correct this imbalance by testing both sedimentary and volcanic rocks used by prehistoric societies. 
In this paper, we analyse chert, shale, and porphyry using indentation testing to investigate three mechanical properties: fracture resistance, elasticity (also known as Young's modulus), and hardness (Table 1). Additionally, traditional petrographic analysis was carried out to assess the mineralogical composition, impurities within the matrix, and individual grain size of minerals that could potentially influence the fracture behaviour of the studied specimens.

\section{Regional setting}

The study areas of the current work are the piedmont and foothill zones of the Qaratau, Ili Alatau, and the Altai-Tarbagatai mountain ranges located in the southern, south-eastern, and eastern Kazakhstan, respectively (Fig. 1). It includes much of the Inner Asian Mountain Corridor (henceforth IAMC) (Frachetti, 2012). The IAMC is a chain of mountain ranges in the centre of the Eurasian continent stretching approximately $2000 \mathrm{~km}$ and occupying most of the Central Asian countries, western China, and Mongolia. Although geologically different, the study areas share common geological formation characteristics, and topographic expressions originate from the tectonic activity, erosion, and other depositional processes. The mountain ranges under study are all affected by a fault system that separates into different sub ranges, i.e., the Greater and Lesser Qaratau.

Many Palaeolithic sites are found in the Qaratau range. Its structural and geological settings have been previously characterised by a number of geologists (Aubekerov and Gorbunov, 1999; Allen et al., 2001; Buslov et al., 2008; Kirscher et al., 2013). The range mainly consists of Neoproterozoic and Palaeozoic bedrocks, and several carbonate seamounts developed due to thermal subsidence of the newly formed crust. The major carbonate platform formed during the Famennian and early Pennsylvanian (Kirscher et al., 2013). The formation of the carbonate platform affected the structure of the Qaratau range being mainly composed of limestone which creates a precondition to form caves, rockshelters and the formation of silica rich rocks within carbonate beds. Such environmental factors played an important role in the human occupation of the region.

Unlike the Qaratau range, the Ili Alatau mountain range (Kazakh portion of the northern Tian Shan) is characterised by steep slopes and the presence of glaciers at higher elevations (Aubekerov and Gorbunov, 1999). The northern foothills enclose vast depression of the Ili and Dzungarian Alatau to the north-east. The mountain foothills are characterised by a blanket of different types of sediments, of which loess covers most of the area. The loess blanket known as the Central Asian piedmont that extends from the Pamir and Alai to the Ili Alatau was extensively studied and defined by Fitzsimmons et al. (2017).

These mountain ranges make up of a highly seasonal region with semi-arid and arid climatic conditions. The position of the mountain groups has played an important role in the early hominin dispersal across Asia (Khatsenovich et al., 2019; Li et al., 2019; Zwyns et al., 2019; Iovita et al., 2020), and possibly provided a refugium during the colder time in Pleistocene (Glantz, 2011; Beeton et al., 2014; Glantz et al., 2016). Already existing archaeological data indicate an extensive human activity, and earlier studies concerning the Palaeolithic of Kazakhstan had already revealed that this region has a potential to study the patterns of human behaviour and migration throughout the Central Asia (Medoev, 1964; Alpysbaev, 1972; Alpysbaev and Kostenko, 1974; Alpysbaev, 1979; Medoev, 1982; Taimagambetov, 1983; 1990; 1997; Derevianko et al., 1999; 2000; Derevianko, 2006; Artyukhova and Mamirov, 2014; Fitzsimmons et al., 2017; Shunkov et al., 2017; Iovita et al., 2020; Namen et al., 2020a).

The studies related to the raw materials of lithic assemblages remain limited. Recent work by Namen et al. (2020b) describes the raw material distribution in the piedmont zones of Kazakhstan using the Centre for Russian and Central EurAsian Mineral Studies (CERCAMS) 
database and discusses the geographic use patterns of different raw materials. According to macroscopic observations of lithic assemblages, every stratified site has a distinctive type of raw material, probably outcropping locally in a close vicinity to the sites. Due to complex geological formations of the piedmont and foothill zones of the IAMC, this region offers a large amount of knappable raw materials. Therefore, the Palaeolithic sites across Kazakhstan has assemblages knapped on variety types of lithologies. Our work showcases these differences by comprehensive investigation of different rocks as well as offers a detailed insight into their mechanical properties. Thus, comparison between sites utilising different lithologies are not meaningful without understanding the limitations that each raw material imposes to the knapper.

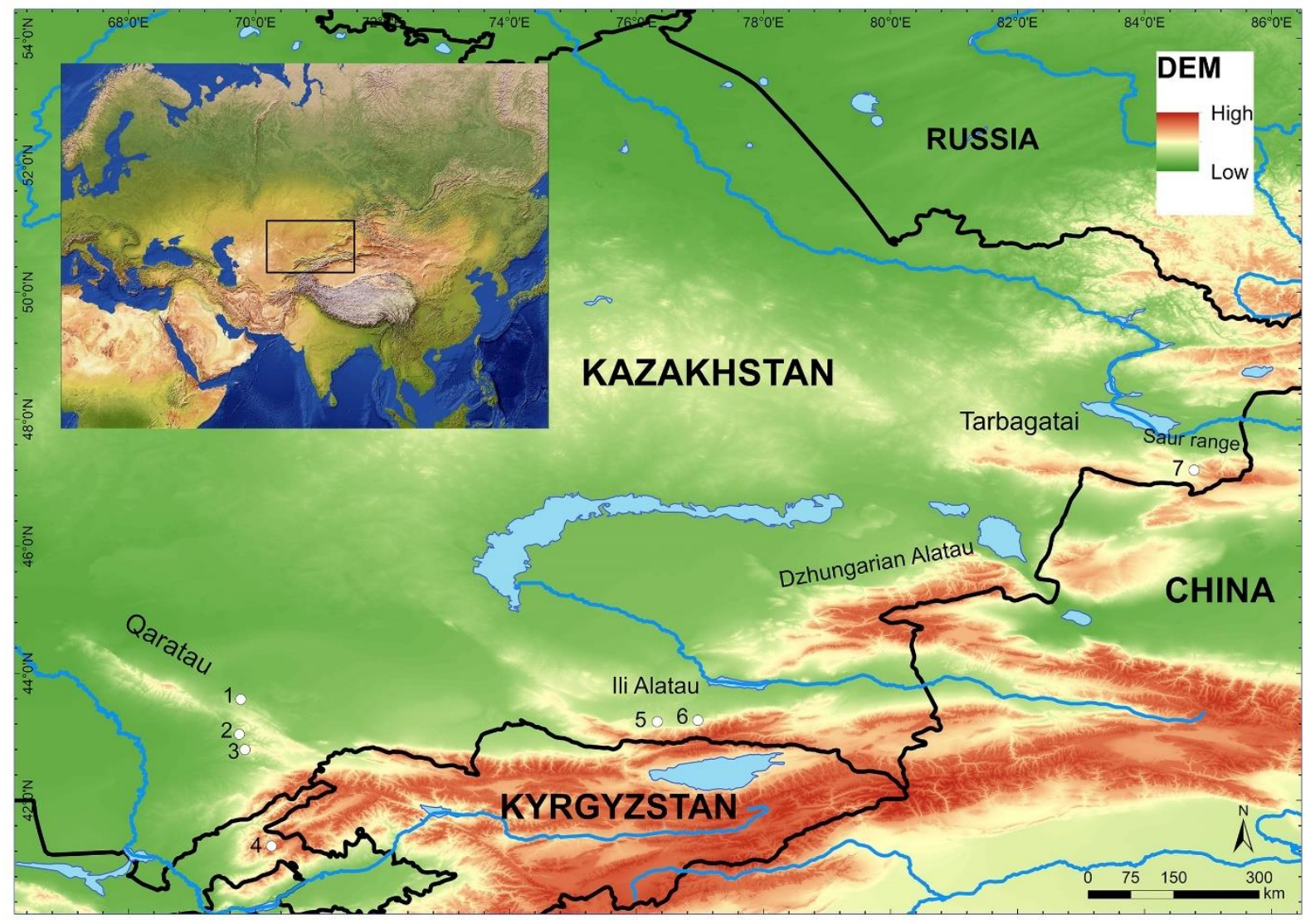

Figure 1. Palaeolithic sites mentioned in the text and illustrated in relation to the major topography of the Inner Asian Mountain Corridor (Kazakh portion). 1) Yntaly. 2) Usiktas (surface site), 3) Valikhanova, 4) Kattasai, Uzbekistan, 5) Maibulaq, 6) Rahat 7) Ushbulaq. Data sources: Global Administrative areas (GADM) (Hijmans, 2012), vector and raster map data from Natural Earth (www.naturalearthdata.com) and Shuttle Radar Topography Mission (SRTM) Version 4 (Jarvis et al., 2008).

Table 1. Description of analysed samples. Localities shown in the table are illustrated on Figure 1. Samples marked with $(*)$ were tested to determine their mechanical properties, the rest were petrographically characterised.

\begin{tabular}{lllll}
\hline Sample ID & Rock type & Location & Sample type & References \\
\hline UBD-1-20* & Dark shale & Ushbulaq, East Kazakhstan & geological & Namen et al. (2020b) \\
UBG-1-20* & Green shale & Ushbulaq, East Kazakhstan & geological & Namen et al. (2020b) \\
YNT-1-20* & Chert & Yntaly, South Kazakhstan & geological & Namen et al. (2020b) \\
MB-1-20* & Porphyry & Maibulaq, South Kazakhstan & archaeological & Fitzsimmons et al. (2017) \\
UT-22* & Chert & Usiktas, South Kazakhstan & archaeological & Alpysbaev, 1979 \\
UT-144* & Chert & Usiktas, South Kazakhstan & archaeological & Alpysbaev, 1979 \\
UB-526* & Dark shale & Ushbulaq, East Kazakhstan & archaeological & Anoikin et al. (2019) \\
UB-537* & Green shale & Ushbulaq, East Kazakhstan & archaeological & Anoikin et al. (2019) \\
\hline
\end{tabular}




\begin{tabular}{lllll}
\hline UB-571 & Green shale & Ushbulaq, East Kazakhstan & archaeological & Anoikin et al. (2019) \\
UB-532 & Dark shale & Ushbulaq, East Kazakhstan & archaeological & Anoikin et al. (2019) \\
UB-492 & Green shale & Ushbulaq, East Kazakhstan & archaeological & Anoikin et al. (2019) \\
UB-514 & Dark shale & Ushbulaq, East Kazakhstan & archaeological & Anoikin et al. (2019) \\
UB-616 & Limestone & Ushbulaq, East Kazakhstan & archaeological & Anoikin et al. (2019) \\
UT-48 & Chert & Usiktas, South Kazakhstan & archaeological & Alpysbaev, 1979 \\
UT-10 & Chert & Usiktas, South Kazakhstan & archaeological & Alpysbaev, 1979 \\
UT-181 & Chert & Usiktas, South Kazakhstan & archaeological & Alpysbaev, 1979 \\
UT-217 & Chert & Usiktas, South Kazakhstan & archaeological & Alpysbaev, 1979 \\
\hline
\end{tabular}

\section{Materials and methods}

\subsection{Samples and sample preparation}

For the current study, we have selected a total of 17 samples, 14 of them are archaeological lithics and the remaining 3 are geological raw materials (Table 1). The geological samples were collected during the PSR project's field campaign conducted in 2018 and 2019 (Namen et al., 2020b; Cuthbertson et al., 2021). Primarily, chert and shale outcrops were surveyed and sampled because they were commonly used as lithic raw materials and produced stone tools in different archaeological sites in the piedmont and foothill zones of the IAMC (Namen et al., 2020b). The archaeological samples of lithics come from the stratified sites of Ushbulaq (Eastern Kazakhstan) (Shunkov et al., 2017; Anoikin et al., 2019), Maibulaq (Almaty region) (Taimagambetov and Ozherelyev, 2008; Taimagambetov, 2009; Fitzsimmons et al., 2017) and a surface site at Usiktas (South Kazakhstan) (Alpysbaev, 1961). Chert can be frequently found in stratified and surface sites throughout southern Kazakhstan, and shale is a major raw material of stone tool assemblages from Ushbulaq. Porphyry was commonly utilised in stratified sites at Maibulaq and Rahat (Ozherelyev et al., 2019). We refer to porphyry as a rock of volcanic origin with crystals visible to the naked eye set in a fine grained matrix. The samples and their descriptions are summarized on Table 1. Location of the sites are shown in Figure 1.

A

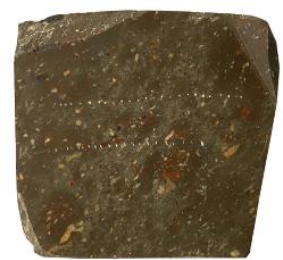

$\mathrm{E}$

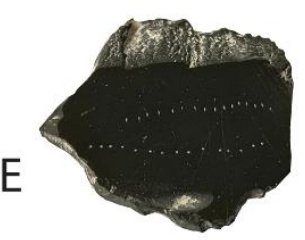

B

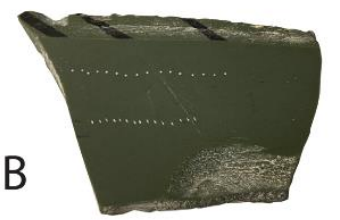

C

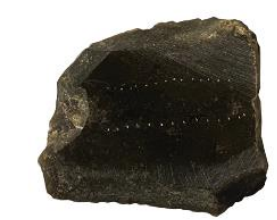

$\mathrm{D}$
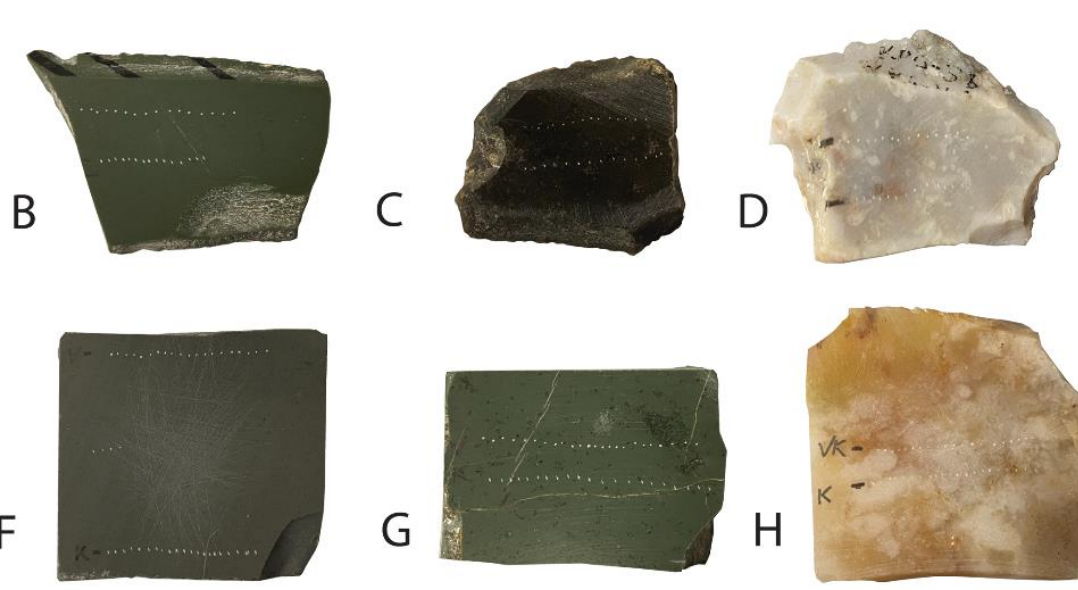

G

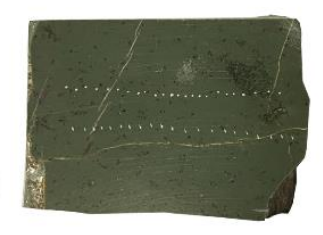

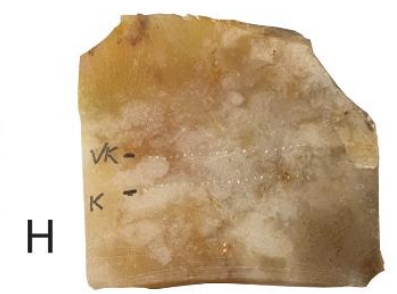

$2 \mathrm{~cm}$

Figure 2. Illustration of archaeological (A-E) and geological (F-H) samples that undergone mechanical testing by means of indentation tests. The dotted lines are the impressions of the diamond indents.

\subsection{The indentation tests}

A total of 8 samples (5 archaeological and 3 geological) were tested to determine their mechanical properties. In order to conduct the analyses, plane-parallel plates measuring 
approximately $40 \times 30 \times 3 \mathrm{~mm}$ (thickness of each sample varies) were cut and diamond polished (see Figure 2) on one side. They were then analysed by the Vickers and Knoop indention.

These indentations provide data on indentation fracture resistance (according to the method proposed by Niihara et al. 1982), Young's modulus (according to the method proposed by Ben Ghorbal et al. 2017) and hardness of each sample. The protocol for indentations was as follows. The load was set to $100 \mathrm{~N}$ (with a pre-load of $10 \mathrm{~N}$ ), speed of indentation $1 \mathrm{~mm} / \mathrm{s}$ and a hold time of $20 \mathrm{~s}$. Both indenters produce either square-shaped or diamond-shaped elongated indentations. The size of each indentation is proportional to material hardness according to equation (1). Another consequence of the indentation of brittle materials with Vickers and Knoop indenters is the formation of half penny-shaped cracks that can be observed at the polished surface. Cracks apparently depart from all four corners of Vickers indentations and from the two acute angle corners of Knoop indentations. The length of the cracks forming from Vickers indentations are proportional to the value of indentation fracture resistance (a value closely related to fracture toughness (see Danzer et al., 2016).

Indentation tests were performed using an Instron 4502 universal testing machine at the laboratory for Applied Mineralogy at Tübingen University's Geosciences department, Germany. Each sample was indented 20 times for each type of indenter to obtain statistically relevant data (see Fig. 2). The size of indentations and cracks was determined using images acquired with a HITACHI Tabletop scanning electron microscope (SEM) TM3030.

Data treatment was as follows. Knoop hardness was calculated by using the formula suggested by Ben Ghorbal et al. (2017). They proposed a way to calculate Knoop hardness that yields results equivalent to the Vickers hardness (equation 12 in Ben Ghorbal et al. 2017):

where,

$$
H K=\frac{P}{\frac{b^{\prime}}{2} \cdot L^{\prime}}
$$

$P$ is the applied load in $\mathrm{KgF}$;

$b^{\prime}$ is the short diagonal of the Knoop indent in $\mathrm{mm}$;

$L^{\prime}$ is the long diagonal of the Knoop indent in $\mathrm{mm}$.

Modulus of elasticity is normally obtained by measuring the potential of a material to deform upon applied stress. However, as bending tests lied outside of the possibilities for this study, we used Ben Ghorbal et al. (2017)'s formula that relies on comparing the long and short diagonals of the Knoop indentations. The calculation was initially suggested by Marshall et al. (1982), but further refined by Ben Ghorbal et al. (2017):

$$
E=0.417 \times H K \div\left(\frac{1}{7.11}-\frac{b^{\prime}}{L^{\prime}}\right)
$$

where,

$H K$ is the Knoop hardness in GPa;

$b^{\prime}$ is the short diagonal of the Knoop indent in $\mu \mathrm{m}$;

$L$ ' is the long diagonal of the Knoop indent in $\mu \mathrm{m}$.

Indentation fracture resistance, as defined by Danzer et al. (2016), closely related to fracture toughness, a measure of a material's resistance to fracture propagation. We use Niihara et al. (1982)'s formula to obtain a value for indentation fracture resistance $\left(K_{I c}\right)$, which uses the length of the surface cracks that develop from the four apical points of the Vickers indentation: 


$$
K_{I c}=0,067 H \sqrt{a}\left(\frac{E}{H}\right)^{0,4}\left(\frac{c}{\mathrm{a}}\right)^{-1,5}
$$

where,

$E$ is Young's modulus in MPa;

$H$ is Vickers hardness in MPa (we used VH here, as calculated from Ben Ghorbal et al. (2017), as the differences between $\mathrm{HV}$ and $\mathrm{HK}$ are negligible when using their calculations);

$c$ is the length of the cracks in $\mu \mathrm{m}$;

$a$ is the diagonal of the Vickers indentation in $\mu \mathrm{m}$.

For this calculation, we admitted that the Knoop hardness is equal to the Vickers hardness and use the value obtained by eq. 1 . Because the size of some of our Vickers indentations could not be accurately determined because their edges flaked off during the experiments, we admitted a standard value of quartz that is equal to $11.65 \mathrm{GPa}$. Diagonals of those indentations with intact margins were measured.

\subsection{Petrographic study}

A total of 16 thin sections, consisting of 12 archaeological samples from surface collections and 4 geological reference samples were microscopically examined. We assessed potential impurities, mineralogical composition, the grain size of quartz grains and relative percentages of clasts and matrix (see Table 4). Traditional petrographic analysis was conducted at the laboratory for Geoarchaeology of the Institute for Archaeological Sciences (INA), University of Tübingen, Germany. The geological and archaeological (surface lithics) samples were prepared following a standard thin section preparation procedure. The thickness of the samples was reduced on a thin section grinder until the thickness of ca. $3 \mu \mathrm{m}$ reached. Thin sections were analysed using a Zeiss petrographic microscope and photomicrographs were obtained using Axio camera coupled to the microscope. Identification and description of minerals were made under plane polarized light (PPL) and cross-polarized light (XPL) following the terminology outlined by Courty et al. (1989) and Stoops (2003).

Thin sections of samples tested for mechanical properties were analysed employing the Image $\mathrm{J}$ software to calculate the percentages of inclusions and matrix which were estimated using the point counting technique (Harwood, 1988). We aimed to identify these components to evaluate whether there is a relationship with mechanical properties or not.

\section{Results}

3 out of 8 samples yielded mechanical values because of the flaking off of all margins which made it impossible to measure indentation diagonals or crack lengths for the other samples. Thus, our results rely on few successful indentations and, therefore, the whole scheme must be regarded with some caution. Here, we present the results obtained from chert, shale, and porphyry as well as describe their petrographic features. Values of hardness, elastic modulus, and indentation fracture resistance are summarised below in Tables $\mathbf{2}$ and 3 and graphically shown in Figures 3-5. Photomicrographs of studied thin sections are shown in Figures 6 and 7.

Table 2. Hardness, elasticity, and fracture resistance values as calculated from the indentation tests. Note: the values of $H V$ and $H K$, and $E$ are given in $\mathrm{GPa}$, and $K_{I c}$ is given in $\mathrm{MPa} \mathrm{m}^{1 / 2}$

\begin{tabular}{lllll}
\hline Sample ID & Rock type & $\boldsymbol{H} \boldsymbol{E}$ & $\boldsymbol{E}$ & $\boldsymbol{K}_{\boldsymbol{I c}}$ \\
\hline UT-22 & Chert & 10.153 & 77 & 2.4 \\
UB-537 & Shale & 4.392 & 153 & 3.01 \\
\hline
\end{tabular}




\begin{tabular}{lllll}
\hline MB-1-20 & Porphyry & 6.730 & 55 & 1.6 \\
\hline
\end{tabular}

Table 3. The values of hardness, elastic modulus, and fracture resistance as calculated from the Vickers and Knoop indentation. Note that the diagonal value $(a)$ was admitted from the standard quartz diagonal due to the flaking off of the edges. It was also admitted as a standard diagonal for the rest of the indented samples.

\begin{tabular}{|c|c|c|c|c|c|c|c|}
\hline \multirow[t]{2}{*}{$\begin{array}{l}\text { Sample } \\
\text { name }\end{array}$} & \multicolumn{2}{|c|}{$\begin{array}{l}\text { Crack length of } \\
\text { Vickers diamond }\end{array}$} & \multicolumn{2}{|c|}{$\begin{array}{l}\text { Crack length of } \\
\text { Knoop diamond }\end{array}$} & \multirow{2}{*}{$\frac{H K}{[G P a]}$} & \multirow{2}{*}{$\frac{E}{[M P a]}$} & \multirow{2}{*}{$\frac{K_{I c}}{\left[M P a m^{1 / 2}\right]}$} \\
\hline & $c[\mu m]$ & $a[\mu m]$ & $L^{\prime}[\mu m]$ & $b^{\prime}[\mu m]$ & & & \\
\hline UT-22 & 188 & 125 & 495 & 36 & 11.179 & 68724 & 2.38 \\
\hline \multirow[t]{9}{*}{ (Chert) } & 188 & 125 & 483 & 44 & 9.283 & 80041 & 2.27 \\
\hline & 188 & 125 & 487 & 37 & 10.984 & 71581 & 2.40 \\
\hline & 188 & 125 & 480 & 34 & 12.093 & 73124 & 2.56 \\
\hline & 188 & 125 & 489 & 41 & 9.786 & 73606 & 2.26 \\
\hline & 188 & 125 & 470 & 37 & 11.411 & 77487 & 2.53 \\
\hline & 188 & 125 & 488 & 48 & 8.368 & 86450 & 2.20 \\
\hline & 188 & 125 & 480 & 44 & 9.418 & 80573 & 2.29 \\
\hline & & & 476 & 43 & 9.644 & 81872 & \\
\hline & & & 483 & 44 & 9.363 & 79105 & \\
\hline UB-537 & 139 & 125 & 590 & 77 & 4.386 & 188498 & 3.17 \\
\hline \multirow[t]{7}{*}{ (Shale) } & 132 & 125 & 603 & 75 & 4.397 & 117266 & 2.84 \\
\hline & 122 & 125 & & & & & \\
\hline & 136 & 125 & & & & & \\
\hline & 122 & 125 & & & & & \\
\hline & 137 & 125 & & & & & \\
\hline & 137 & 125 & & & & & \\
\hline & 156 & 125 & & & & & \\
\hline MB-1-20 & 200 & 125 & 551 & 49 & 7.298 & 60380 & 1.59 \\
\hline \multirow[t]{11}{*}{ (Porphyry) } & 177 & 125 & 601 & 53 & 6.162 & 50410 & 1.61 \\
\hline & 204 & 125 & & & & & \\
\hline & 182 & 125 & & & & & \\
\hline & 199 & 125 & & & & & \\
\hline & 195 & 125 & & & & & \\
\hline & 102 & 125 & & & & & \\
\hline & 182 & 125 & & & & & \\
\hline & 155 & 125 & & & & & \\
\hline & 143 & 125 & & & & & \\
\hline & 147 & 125 & & & & & \\
\hline & 176 & 125 & & & & & \\
\hline
\end{tabular}

\subsection{Indentation tests}

Among the three different types of lithologies studied, chert (UT-22) shows the highest hardness value of over $10 \mathrm{GPa}$ compared to $6.730 \mathrm{GPa}$ of porphyry (MB-1-20) and $4.392 \mathrm{GPa}$ of shale (UB-537). Based on these experiment results, hardness of shale is lowest as compared to the other two rocks. 


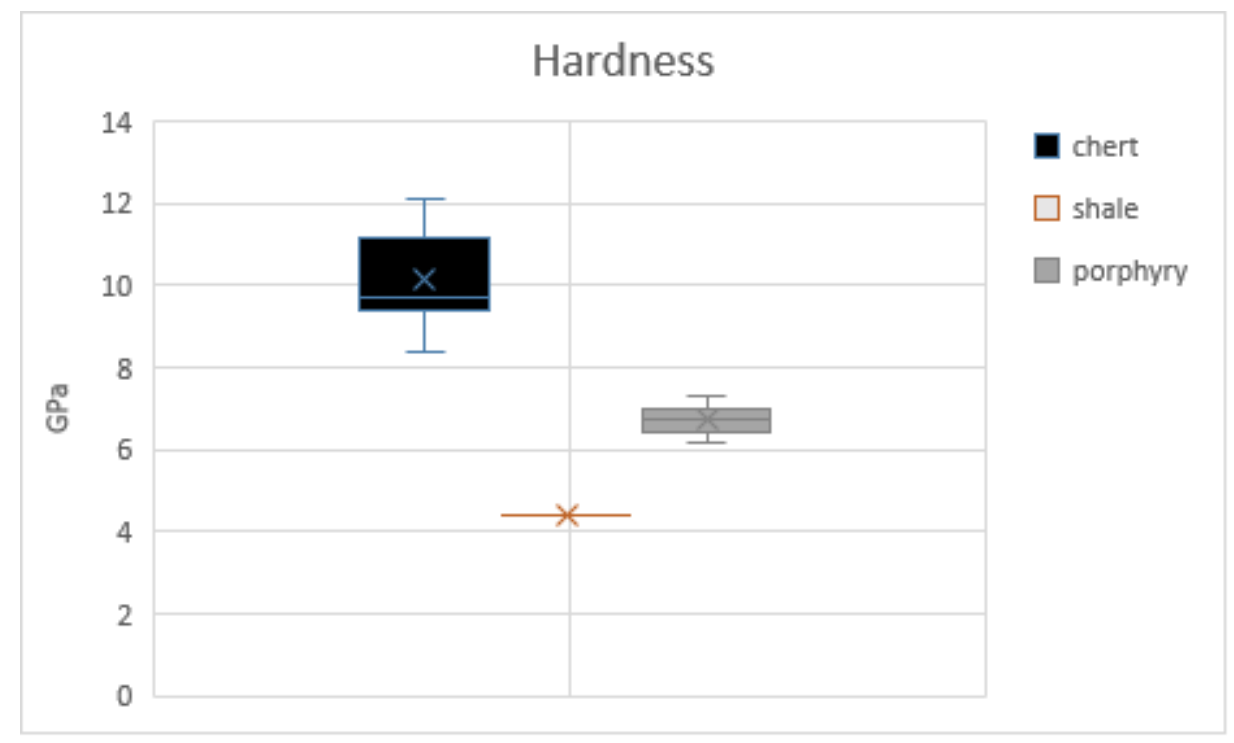

Figure 3. The hardness values.

The modulus of elasticity, calculated using eq. 2, suggests that porphyry is the less stiff material with a mean value equal to $55 \mathrm{GPa}$. Whereas chert yielded $77 \mathrm{GPa}$ and shale is the stiffest rock among studied lithologies with an $E$ value of $153 \mathrm{GPa}$. Although porphyry is a volcanic rock that contains relatively large phenocrysts of quartz and feldspar, our results suggest that it is less stiff than the other two analysed samples.

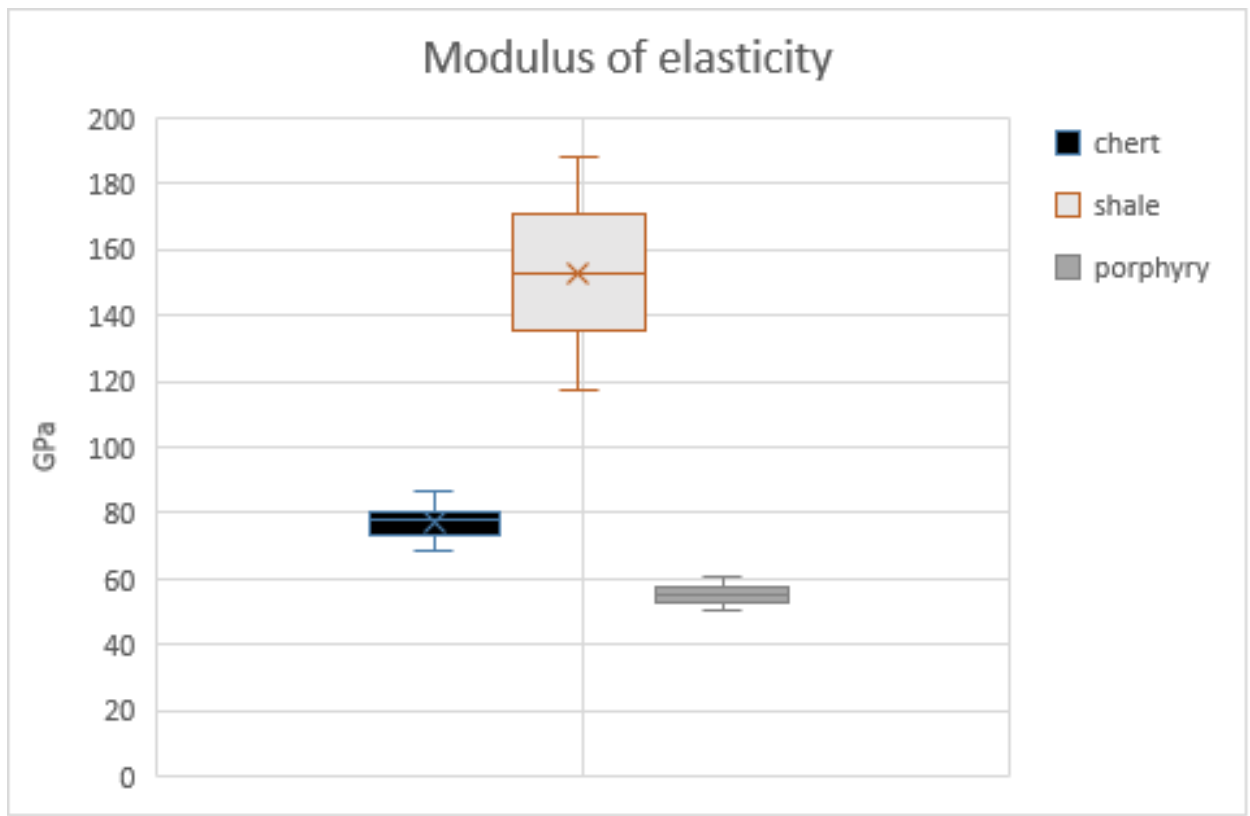

Figure 4. The modulus of elasticity values.

The $K_{I c}$ values suggest that shale is most resistant to fracture with a mean value of $3.01 \mathrm{MPa}$ $\mathrm{m}^{1 / 2}$. The samples of chert and porphyry have a value equal to 2.4 and $1.6 \mathrm{MPa} \mathrm{m} \mathrm{m}^{1 / 2}$, respectively. These data may suggest that among three lithologies fracture propagates without consuming much energy in porphyry than in those of shale and chert. However, more detailed investigation of rock strength is required to determine whether lower $K_{I c}$ value equals to easier flake detachment. 


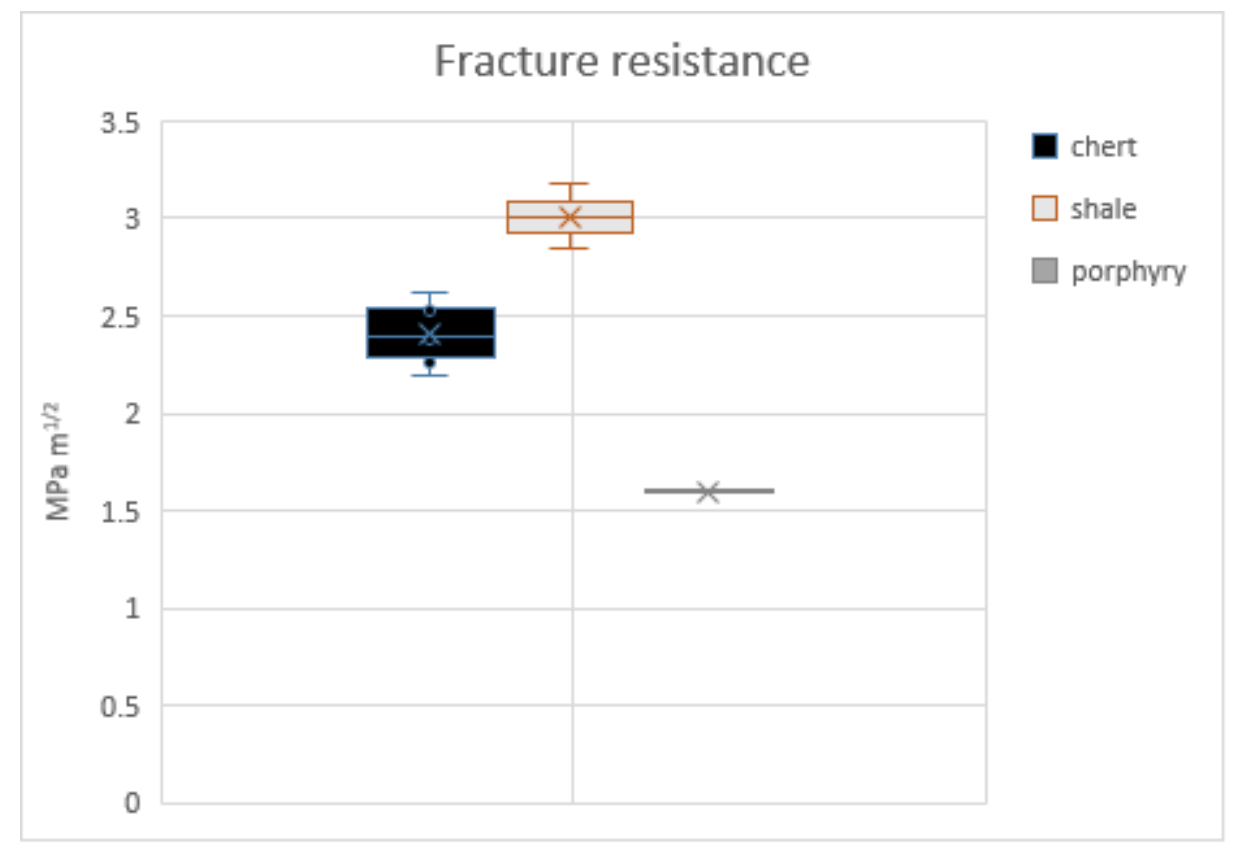

Figure 5. The fracture resistance of studied samples.

\subsection{Petrography}

Table 3 summarizes the petrographic characteristics of the studied rock samples. Prior to petrographic analysis, samples were macroscopically identified as shale, chert, limestone, and porphyry.

During petrographic analysis, two types of shales were distinguished: calcareous shale (for instance UBG-1-20) mainly comprised of well-sorted, from subrounded to rounded crystals of calcite and quartz supported by a possibly calcareous matrix. Calcite grains within shale is of secondary origin which was recrystallised during later rock diagenesis. The second type is siliceous shale (UBD-1-20) that consists of subrounded grains of feldspar and quartz. Thin sections prepared from archaeological lithics from Ushbulaq $(n=6)$ show similar petrographic characteristics as the geological samples with a varying degree of quartz, calcite, and feldspar inclusions with the exception of sample UB-616.

The thin sections of archaeological lithics from Usiktas $(n=6)$ are entirely composed of lengthfast chalcedony similar to the geological sample of YNT-1-20 (Yntaly chert). Microscopically, these samples have similar microstructure. However, we do not suggest that these lithic raw materials were transported from Yntaly, we only note their structural similarity. The presence of impurities and other minerals within chert samples are not observed. A thin section of porphyry from Maibulaq (MB-1-20) is comprised of coarse and angular grains of quartz and feldspar supported by a siliceous matrix. An inclusion of xenoliths, possibly broken off from the magma chamber or conduit walls around the time of eruption was observed (Fig. 6A). 

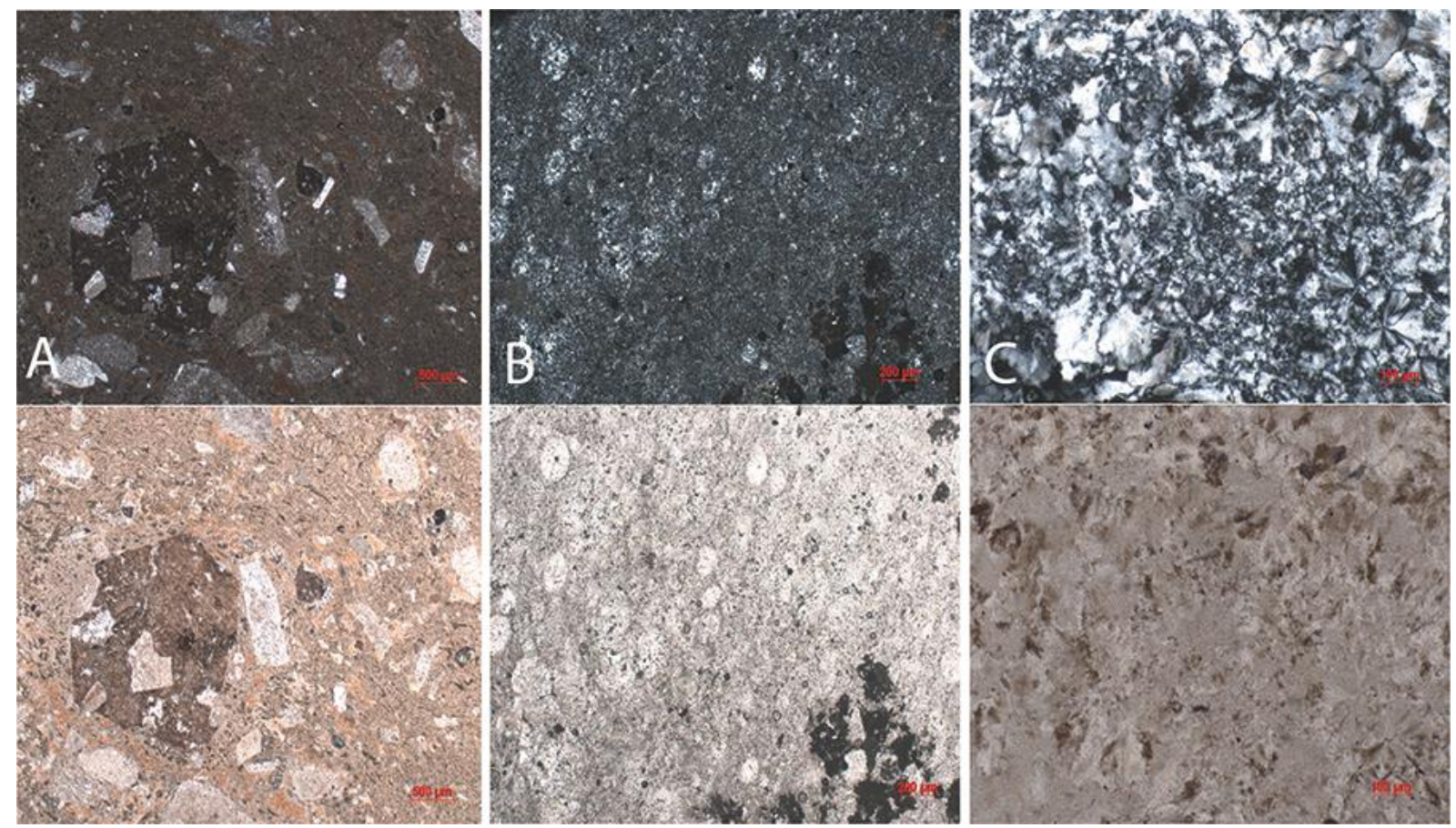

Figure 6. Photomicrographs of A) porphyry, B) shale, and C) chert under XPL (upper) and PPL (lower) lights that were tested by means of indentation.

Table 4. Basic petrographic description of archaeological and geological thin sections.

\begin{tabular}{|c|c|c|c|}
\hline Sample ID & Rock type & Matrix & Description \\
\hline MB-1-20 & $\begin{array}{l}\text { Porphyry } \\
\text { (Rhyolite ?) }\end{array}$ & Siliceous & $\begin{array}{l}\text { Coarse and angular grains of quartz, feldspar, and sericite, a } \\
\text { product of hydrothermal alteration of feldspar, minerals } \\
\text { embedded in a fine-grained siliceous matrix. Large xenolith is } \\
\text { observed. }\end{array}$ \\
\hline UBD-1-20 & Dark shale & Calcareous & $\begin{array}{l}\text { Fine-grained, rounded and subrounded grains of quartz and } \\
\text { calcite are supported by a calcareous matrix. }\end{array}$ \\
\hline UBG-1-20 & Green shale & Siliceous & $\begin{array}{l}\text { Moderately sorted, subrounded grains of quartz and feldspar, } \\
\text { and fine-grained calcite minerals are supported by a siliceous } \\
\text { matrix. }\end{array}$ \\
\hline YNT-1-20 & Chert & Siliceous & Entirely composed of length-fast chalcedony \\
\hline UB-537 & Dark shale & Siliceous & $\begin{array}{l}\text { Rounded, microcrystalline quartz grains embedded in a } \\
\text { siliceous matrix. }\end{array}$ \\
\hline UB-492 & Green shale & Siliceous & $\begin{array}{l}\text { Subrounded grains of quartz and calcite supported by a } \\
\text { siliceous matrix. }\end{array}$ \\
\hline UT-48 & Chert & Siliceous & Entirely composed of length-fast chalcedony. \\
\hline UT-10 & Chert & Siliceous & Entirely composed of length-fast chalcedony. \\
\hline UT-181 & Chert & Siliceous & Entirely composed of length-fast chalcedony. \\
\hline UT-144 & Chert & Siliceous & Entirely composed of length-fast chalcedony. \\
\hline UT-22 & Chert & Siliceous & Entirely composed of length-fast chalcedony. \\
\hline UT-217 & Chert & Siliceous & Entirely composed of length-fast chalcedony. \\
\hline UB-571 & Green shale & Siliceous & $\begin{array}{l}\text { Primarily composed of well-rounded, well-sorted quartz grains, } \\
\text { few inclusions of angular feldspar can be observed. }\end{array}$ \\
\hline UB-532 & Dark shale & Siliceous & $\begin{array}{l}\text { Composed of primarily well-sorted calcite and few quartz } \\
\text { minerals, several internal cracks are filled with calcite. }\end{array}$ \\
\hline UB-514 & Dark shale & Siliceous & $\begin{array}{l}\text { Subrounded grains of clay sized quartz supported on a siliceous } \\
\text { matrix. }\end{array}$ \\
\hline UB-616 & $\begin{array}{l}\text { Silicified } \\
\text { limestone (?) }\end{array}$ & Calcareous & Silicified limestone. \\
\hline
\end{tabular}

In addition, individual grain sizes of quartz, percentage of inclusions and matrix of indented samples (see subchapter 4.1 and Table 1) has been measured and shown in Table 4. This is done to examine whether petrographic characteristics (grain size, number of inclusions and matrix) affects the fracture resistance of tested rocks. As expected, porphyry contains the largest 
grain size among other studied samples. These clasts are also visible to the naked eye. The geological samples of shale contain relatively large mineral grains with a mean size equal to $299.5 \mu \mathrm{m}$, whereas the grain size of archaeological lithic is much smaller and equals to 41.9 $\mu \mathrm{m}$. Average grain size of chert could not be measured due to the cryptocrystalline nature of quartz grains in chalcedony.

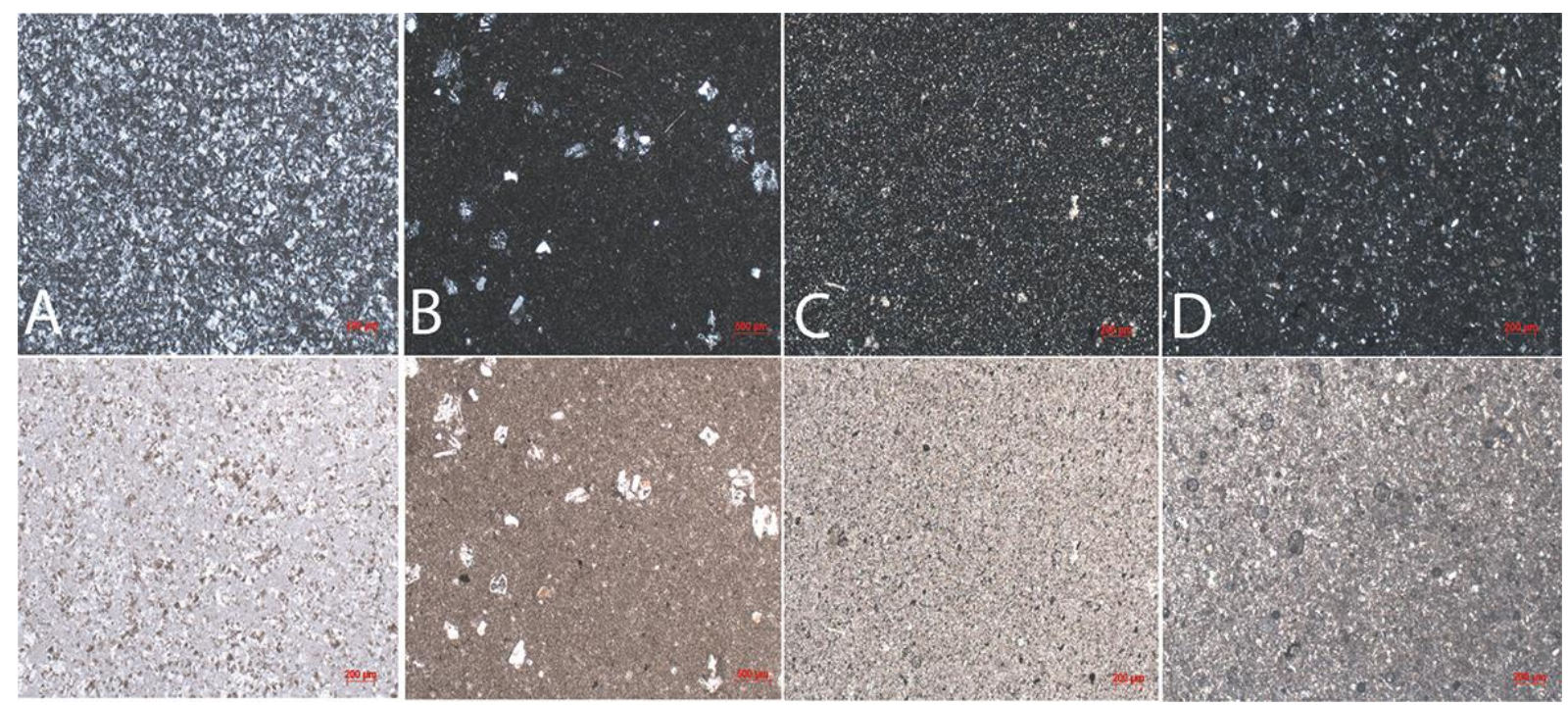

Figure 7. Photomicrographs of A) chert, B) calcareous shale, C-D) and siliceous shale under XPL (upper) and PPL (lower) lights.

Table 5. Grain size of quartz minerals and percentage of inclusions and matrix. CC stands for cryptocrystalline grain size $(<1 \mu \mathrm{m})$. Note: samples marked with $(*)$ were tested to determine their mechanical properties.

\begin{tabular}{lcccccc}
\hline Sample ID & Rock type & \% inclusions & \% matrix & \multicolumn{3}{c}{ Quartz } \\
\cline { 5 - 6 } & & & & Min $(\boldsymbol{\mu m})$ & Max $(\boldsymbol{\mu m})$ & Mean $(\boldsymbol{\mu m})$ \\
\hline UBD-1-20 & Dark shale & 34.7 & 55.1 & 146.6 & 566.2 & 299.5 \\
UBG-1-20 & Green shale & 10.2 & 89.8 & 77.2 & 740.8 & 386.9 \\
MB-1-20* & Porphyry & 32.9 & 60.6 & 409.5 & 2241.9 & 1125.4 \\
UB-537* & Shale & 55.1 & 61.3 & 25.1 & 89.3 & 41.9 \\
UT-22* & Chert & CC & CC & CC & CC & CC \\
\hline
\end{tabular}

\section{Discussion}

This experimental work is one of the first to be implemented for the Palaeolithic of Kazakhstan. However, our discussion relies on few successful indentations (Table 3) and, therefore, the whole scheme must be regarded with some caution. Despite the small size of studied samples, this work offers insights into some mechanical properties of chert, shale, and porphyry that add to the knowledge of the knapping technology and stone tool assemblage formation. The results suggest that the raw materials considered as a lower quality material (porphyry) due to the presence of large phenocrysts, in fact, have mechanical properties (e.g., fracture resistance and modulus of elasticity) that can be compared to the materials that are considered to be of higher quality, i.e., chert and silcrete studied by Schmidt et al. (2019).

\subsection{Raw material quality}

The studied mechanical properties allow us to have a preliminary discussion on raw material quality. Our results suggest that chert is the hardest material, harder than porphyry and shale. This is expected since it is entirely composed of length-fast chalcedony, which in turn is quartz (with an average hardness of $\sim 12 \mathrm{GPa}$ ). On the other hand, shale has a lower hardness value in spite of its siliceous matrix and primarily quartz composition as seen under microscope. 
Although impurities within the shale have not been observed during our petrographic study, the lower overall hardness of the rock could be due the presence of clay impurities within the shale microstructure that was not detectable under 40x magnification (Lawn and Wilshaw, 1975). The $E$ values obtained from our experiments likewise show significant differences between chert, shale, and porphyry. Even though chert is composed of chalcedony and shale consists primarily of microcrystalline quartz, the elasticity values of chert and shale differ greatly, too. On the other hand, the $E$ values of porphyry are lower than those of chert and shale. In the analysis of mechanical properties of heat-treated silcrete, Schmidt et al. (2019) observed that silcretes with more (abundant) clasts generally had a strong loss of $E$ values upon heat treatment compared to finer silcrete. This means that structural differences developed during the heat treatment process may affect the elasticity value (Schmidt et al., 2019). This is also supported by our observations on the relationship of grain size and mechanical properties of the rocks. For instance, our investigation shows that samples (porphyry) with bigger grain size have lower modulus of elasticity. Also, based on the measurements using the point counting technique of grain size, inclusions, and matrix, samples with lower percentages of each component demonstrate lower value of indentation fracture resistance (Table 5). An experimental investigation by Huang and Wang (1985) on the impact of petrological characteristics, particularly of grain size to fracture toughness, suggest the dependence of these two parameters. However, due to the small size and unheated nature of studied samples compared to the thermally altered silcretes, our results should be considered with some caution. Further investigations involving larger number of samples will be required to assess whether the large grain size affected the mechanical properties of our porphyry or not.

Generally, the modulus of elasticity is proportional to the stiffness of the material. Domanski et al. (1994) states that the modulus of elasticity is an important measure of the suitability of materials for blade manufacture, because stiffness-controlled fracture propagation is basically responsible for blade detachment (Cotterell and Kamminga 1987).

The mean values of $K_{I c}$ have a linear correlation with the $E$ values meaning that samples with the lowest $E$ values also present low $K_{I c}$ values and vice versa (see Fig. 3 and 4). The lower values of $K_{I c}$ imply less resistance against fracture suggesting that the material is easier to fracture and perhaps also to knap tools. Thus, our $K_{I c}$ suggest good knapping quality of porphyry, despite observations to the contrary (see subchapter $\mathbf{5 . 2}$ for discussion). Also, the modulus of elasticity and fracture resistance values of porphyry (see Table 2) can be compared to those of chert and silcrete obtained by Schmidt et al. (2019). However, the meaning of $K_{I c}$ for the actual knapping properties observed during experimental knapping should be investigated in the future.

It is the first-time experiments such as this is being conducted to investigate the mechanical properties of archaeological porphyry. Our results offer a preliminary insight into the knapping quality of this rock. Further experimental lithic knapping or research on other mechanical properties (e.g., fracture strength) is necessary to examine the factors that affect the flaking of investigated samples. Similar research specifically targeting the evolution of mechanical properties of silica rocks upon heat treatment allow us to compare the $K_{I c}$ values with previously published data and verify the results. For instance, the fracture resistance values of chert and silcrete from Schmidt et al. (2019) study vary from 1.3 to $1.85 \mathrm{MPa} \mathrm{m}^{1 / 2}$. The resistance values of our samples vary between 1.6 and $2.4 \mathrm{MPa} \mathrm{m}^{1 / 2}$ and therefore support previous works.

\subsection{Implications for stone tool knapping}

Comparing the results of the experimental works with the stone tool knapping of various Upper Palaeolithic sites shows a pattern that allows us to preliminarily discuss the effect of raw material quality to the stone tool knapping technology. Although homogeneous, isotropic, fine- 
grained, and silica rich rocks were normally preferred for the manufacture of stone tools, evidence of the utilisation of locally available, and primarily considered of "lower" quality materials such as porphyry is known in Central Asian stratified Palaeolithic sites of Rahat and Maibulaq in Kazakhstan (Taimagambetov, 2009; Ozherelyev et al., 2019), and Kattasai-1 and Kattasai-2 in Uzbekistan (Krajcarz et al., 2015; Kot et al., 2020). We primarily concentrate our discussion on the quality of porphyry and the major techno-typological similarities between Palaeolithic industries that utilised it as a principal raw material.

Since porphyry was locally available as river pebbles, the large proportion of lithics knapped at the aforementioned sites were on this material. The use of higher quality exogeneous raw materials such as chert is common, but in much smaller quantities. Based on comprehensive literature review, we observed the presence of Levallois or Levallois-like technologies in all sites that utilise porphyry (Taimagambetov, 2009; Krajcarz et al., 2015; Ozherelyev et al., 2019; Kot et al., 2020). The lithic analysis of Kattasai-1 assemblage determined several schemes of reduction. The radial reduction of cores is predominant along with single and double platform parallel reduction (Pavlenok et al., 2021). Similar knapping technology was defined in both Maibulaq and Rahat. Besides the Middle Palaeolithic character of the Kattasai-1 and Upper Palaeolithic assemblages from Maibulaq and Rahat, technological analogies clearly demonstrate the link between the raw material quality and reduction strategies. We hypothesise that these similarities could be linked to the mechanical properties of porphyry. Additionally, our results suggest that porphyry has at least some properties that can be compared with those of chert. However, compared to chert porphyry is a coarse grained volcanic rock with a siliceous matrix (see Table 4). In coarser grained rocks the fracture propagates as both transgranular and intergranular cracks, thus consuming less energy to detach a flake of a desired morphology (Mardon et al., 1990). Moreover, the presence of bladelets knapped on both porphyry and shale from Maibulaq demonstrates the suitability for the production of smaller tools. The fracture resistance, elasticity, and hardness values obtained from our mechanical tests also attest the suitability for the knapping of blades and bladelets. This data allows us to hypothesise that hominins that once occupied these sites had to adapt the stone knapping technology to the quality and availability of resources. In addition to the grain size of porphyry, we observed that cobbles currently available in the Maibulaq stream bed today tend to have higher incidence of large phenocrysts than those encountered in the archaeological collection. Exploring this pattern with a sample of both raw material and archaeological stone tools could potentially indicate that prehistoric communities at Maibulaq deliberately selected rocks with smaller phenocrysts for knapping, but this must be tested with further analyses of raw materials and archaeological stone tools.

\section{Conclusions}

The present study for the first time tests fracture resistance, hardness, and modulus of elasticity of unheated samples of archaeological lithics and rocks from various Upper Palaeolithic sites in Kazakhstan. It also offers first insight into the quality of archaeological porphyry which was used as a principal raw material at various Upper Palaeolithic sites in the foothill and piedmont zones of the IAMC. We conclude that raw materials that were previously thought to be of lower quality (e.g., porphyry), in fact have some mechanical properties similar to those of chert. The prehistoric knappers that inhabited the northern foothills of the IAMC adapted the lithic reduction schemes to the quality of available raw material such as porphyry. The presence of levallois or levallois-like technology that can be observed from several Upper Palaeolithic sites that utilise porphyry as a main raw material support this hypothesis. 
This work highlights the importance of the mechanical properties of chert, shale, and porphyry and its effect to the production of stone tools. Our findings show that materials that are expected to be difficult to knap based on visual criteria, objectively may have some good fracture properties. Hominins were most likely aware of this, and this kind of analysis shows that we have to base our conclusions on objective criteria rather than subjective ones. The porphyry case is a surprise because it is rarely used for knapping, and mainly unfamiliar to archaeologists. However, these kinds of counterintuitive results are also likely for some materials that are familiar to archaeologists, such as different types of cherts, basalts, and others.

Further investigations involving larger number and various types of raw materials and archaeological lithics are necessary to study and eventually build a catalogue of the mechanical properties of different raw materials from Kazakhstan. Our preliminary data can serve as a baseline for future quantitative and experimental investigations.

\section{Acknowledgements}

We would like to thank Dean Mendigul Nogaibaeva, Prof. Gani Omarov and Dr. Rinat Zhumatayev (Department of Archaeology, Ethnology and Museology, Faculty of History, Ethnology and Archaeology, Al Farabi Kazakhstan National University) for their support of this work. A. Namen would like to thank Prof. Dr. Christopher Miller for his support of this research, and access to the equipment of the Geoarchaeology laboratory at the Institute for Archaeological Sciences, in the University of Tübingen. The current study was performed within the PALAEOSILKROAD project and all field research was conducted under license No. 15008746 (12.05.2015) of the National Museum of the Republic of Kazakhstan based on the collaboration protocol between the Eberhard-Karls University of Tübingen and the National Museum. This project has received funding from the European Research Council (ERC) under the European Union's Horizon 2020 research and innovation programme (grant agreement $\mathrm{n}^{\circ}$ 714842; PALAEOSILKROAD project).

\section{Bibliography}

Allen, M.B., Alsop, G.I., Zhemchuzhnikov, V.G., 2001. Dome and basin refolding and transpressive inversion along the Karatau Fault System, southern Kazakstan. Journal of the Geological Society 158, 83-95. doi:10.1144/jgs.158.1.83

Alpysbaev, Kh., 1961. Novye paleoliticheskie mestonakhozhdeniya v basseine rek Arystandy - Buryltai (Borolodai) v Yuzhnom Kazakhstane [New Paleolithic Locations in the Arystandy - Buryltai (Boroldai) River Basin in Southern Kazakhstan]. In: Novye materialy po arkheologii i etnografii Kazakhstana. Izdat. A. N. KazSSR, Alma-Ata, pp. 3-20.

Alpysbaev, Kh., 1972. O lokal'nykh razlichiyakh paleoliticheskikh kul'tur Srednei Azii i Kazakhstana [On local differences of the Paleolithic cultures of Central Asia and Kazakhstan]. In: Uspekhi sredneaziatskoi arkheologii. Nauka, Leningrad, pp. 5-7.

Alpysbaev, Kh., 1979. Pamyatniki nizhnego paleolita yuzhnogo Kazakhstana [Lower Paleolithic sites of Southern Kazakhstan]. Nauka, Alma-Ata.

Alpysbaev, Kh., Kostenko, N., 1974. Stratigraficheskie usloviya nekotorykh paleoliticheskikh stoyanok Yuzhnogo Kazakhstana [Stratigraphic conditions of some Palaeolithic sites of southern Kazakhstan]. In: V glub' vekov (arkheologicheskii sbornik). Nauka KazSSR, Alma-Ata, pp. 315.

Andrefsky, W., 1994. The geological occurrence of lithic material and stone tool production strategies. Geoarchaeology 9, 375-391. doi:10.1002/gea.3340090503

Anoikin, A.A., Pavlenok, G.D., Kharevich, V.M., Taimagambetov, Z.K., Shalagina, A.V., Gladyshev, S.A., Duvanbekov, R.S., Shunkov, M.V., 2019. Ushbulak - novaya mnogosloinaya stoyanka verkhnego paleolita na severo-vostoke Kazakhstana [Ushbulak - a new stratfied Upper Paleolithic site in Northeastern Kazakhstan]. Archaeology, Ethnography and Anthropology of Eurasia 47, 16-29. doi:10.17746/1563-0102.2019.47.4.016-029 
Artyukhova, O.A., Mamirov, T.B., 2014. Kamennyi vek Saryarki: evolutsiya kultur ot drevnepaleoliticheskikh okhotnikov do pervykh metallurgov v svete noveishikh issledovaniy [Stone Age of Saryarka: the evolution of cultures from ancient Paleolithic hunters to the first metallurgists in the light of the latest research]. Institut arkheologii A. Kh. Margulana, Almaty.

Aubekerov, B., Gorbunov, A., 1999. Quaternary permafrost and mountain glaciation in Kazakhstan. Permafrost and Periglacial Processes 10, 65-80. doi:10.1002/(SICI)10991530(199901/03)10:1<65::AID-PPP306>3.0.CO;2-X

Beeton, T.A., Glantz, M.M., Trainer, A.K., Temirbekov, S.S., Reich, R.M., 2014. The fundamental hominin niche in late Pleistocene Central Asia: a preliminary refugium model. Journal of Biogeography 41, 95-110. doi:10.1111/jbi.12183

Ben Ghorbal, G., Tricoteaux, A., Thuault, A., Louis, G., Chicot, D., 2017. Comparison of conventional Knoop and Vickers hardness of ceramic materials. Journal of the European Ceramic Society 37, 2531-2535. doi:10.1016/j.jeurceramsoc.2017.02.014

Brantingham, P.J., Olsen, J.W., Rech, J.A., Krivoshapkin, A.I., 2000. Raw Material Quality and Prepared Core Technologies in Northeast Asia. Journal of Archaeological Science 27, 255-271. doi:10.1006/jasc. 1999.0456

Braun, D.R., Plummer, T., Ferraro, J.V., Ditchfield, P., Bishop, L.C., 2009. Raw material quality and Oldowan hominin toolstone preferences: evidence from Kanjera South, Kenya. Journal of Archaeological Science 36, 1605-1614. doi:10.1016/j.jas.2009.03.025

Buslov, M.M., Kokh, D.A., De Grave, J., 2008. Mesozoic-Cenozoic tectonics and geodynamics of Altai, Tien Shan, and Northern Kazakhstan, from apatite fission-track data. Russian Geology and Geophysics 49, 648-654. doi:10.1016/j.rgg.2008.01.006

Collins, S., 2008. Experimental investigations into edge performance and its implications for stone artefact reduction modelling. Journal of Archaeological Science 7.

Cotterell, B., Kamminga, J., 1987. The Formation of Flakes. American Antiquity 52, 675-708. doi:10.2307/281378

Cotterell, B., Kamminga, J., Dickson, F.P., 1985. The essential mechanics of conchoidal flaking. International Journal of Fracture 29, 205-221. doi:10.1007/BF00125471

Courty, Goldberg, P., Macphail, R., 1989. Soils and Micromorphology in Archaeology. Cambridge University Press.

Crabtree, D.E., 1967. Notes on Experiments in Flintknapping 3: The Flintknapper's Raw Materials. Tehiwa 10, 8-25.

Cuthbertson, P., Ullmann, T., Büdel, C., Varis, A., Namen, A., Seltmann, R., Reed, D., Taimagambetov, Z., Iovita, R., 2021. Finding karstic caves and rockshelters in the Inner Asian mountain corridor using predictive modelling and field survey. PLOS ONE 16, e0245170. doi:10.1371/journal.pone. 0245170

Danzer, R., Lube, T., Rasche, S., 2016. On the Development of Experimental Methods for the Determination of Fracture Mechanical Parameters of Ceramics. In: Hütter, G., Zybell, L. (Eds.), Recent Trends in Fracture and Damage Mechanics. Springer International Publishing, Cham, pp. 197-214. doi:10.1007/978-3-319-21467-2_8

Derevianko, A.P., 2006. The lower paleolithic small tool industry in Eurasia: Migration or convergent evolution? Archaeology, Ethnology and Anthropology of Eurasia 25, 2-32. doi:10.1134/S1563011006010014

Derevianko, A.P., Petrin, V.T., Taimagambetov, Z.K., Zenin, A.N., Gladyshev, S.A., 1999. Paleoliticheskie kompleksy poverhnostnogo zaleganiya Mugodzharskih gor [Surface Paleolithic complexes of the Mugodzharian mountains]. Problemy arxeologii, etnografii, antropologii Sibiri i sopredel'nyh teritoriy 5, 50-55.

Derevianko, A.P., Petrin, V.T., Taimagambetov, Ž.K., Isabekov, Z.K., Rybalko, R.G., Otte, M., 2000. Rannepaleoliticheskie mikroindustrial'nye compleksy v travertinakh yuzhnogo Kazakhstana [Lower Paleolithic microindustrial travertine complexes of Southern Kazakhstan], Izd-vo IAE SB RAS. Russian Academy of Sciences, Siberian Branch, Novosibirsk.

Dogandžić, T., Abdolazadeh, A., Leader, G., Li, L., McPherron, S.P., Tennie, C., Dibble, H.L., 2020. The results of lithic experiments performed on glass cores are applicable to other raw materials. Archaeological and Anthropological Sciences 12, 44. doi:10.1007/s12520-019-00963-9

Domanski, M., Webb, J., 2007. A Review of Heat Treatment Research. Lithic Technology 32, 153-194. doi:10.1080/01977261.2007.11721052 
Domanski, M., Webb, J.A., Boland, J., 1994. Mechanical properties of stone artefact materials and the effect of heat treatment. Archaeometry 36, 177-208. doi:10.1111/j.1475-4754.1994.tb00963.x

Fitzsimmons, K.E., Iovita, R., Sprafke, T., Glantz, M., Talamo, S., Horton, K., Beeton, T., Alipova, S., Bekseitov, G., Ospanov, Y., Deom, J.-M., Sala, R., Taimagambetov, Z., 2017. A chronological framework connecting the early Upper Palaeolithic across the Central Asian piedmont. Journal of Human Evolution 113, 107-126. doi:10.1016/j.jhevol.2017.07.006

Frachetti, M.D., 2012. Multiregional Emergence of Mobile Pastoralism and Nonuniform Institutional Complexity across Eurasia. Current Anthropology 53, 2-38. doi:10.1086/663692

Glantz, M., Van Arsdale, A., Temirbekov, S., Beeton, T., 2016. How to survive the glacial apocalypse: Hominin mobility strategies in late Pleistocene Central Asia. Quaternary International. doi:10.1016/j.quaint.2016.06.037

Glantz, M.M., 2011. The History of Hominin Occupation of Central Asia in Review. In: Norton, C.J., Braun, D.R. (Eds.), Asian Paleoanthropology, Vertebrate Paleobiology and Paleoanthropology. Springer Netherlands, Dordrecht, pp. 101-112. doi:10.1007/978-90-481-9094-2_8

Goldman-Neuman, T., Hovers, E., 2012. Raw material selectivity in Late Pliocene Oldowan sites in the Makaamitalu Basin, Hadar, Ethiopia. Journal of Human Evolution 62, 353-366. doi:10.1016/j.jhevol.2011.05.006

Goodman, M.E., 1944. The Physical Properties of Stone Tool Materials. American Antiquity 9, 415433. doi: $10.2307 / 275093$

Harwood, G., 1988. Microscopic techniques: II. principles of sedimentary petrography. In: Techniques in Sedimentology. Blackwell Scientific, Oxford, pp. 73-108.

Hijmans, R., 2012. GADM database of global administrative areas (version 2.0).

Huang, J.-A., Wang, S., 1985. An experimental investigation concerning the comprehensive fracture toughness of some brittle rocks. International Journal of Rock Mechanics and Mining Sciences \& Geomechanics Abstracts 22, 99-104. doi:10.1016/0148-9062(85)92331-9

Iovita, R., Varis, A., Namen, A., Cuthbertson, P., Taimagambetov, Z., Miller, C.E., 2020. In search of a Paleolithic Silk Road in Kazakhstan. Quaternary International 559, 119-132. doi:10.1016/j.quaint.2020.02.023

Jarvis, A., Reuter, H.I., Nelson, A., Guevara, E., 2008. Hole-filled SRTM for the globe Version 4.

Khatsenovich, A.M., Rybin, E.P., Bazargur, D., Marchenko, D.V., Kogai, S.A., Shevchenko, T.A., Klementiev, A.M., Gunchinsuren, B., Olsen, J.W., 2019. Middle Palaeolithic human dispersal in Central Asia: new archaeological investigations in the Orkhon Valley, Mongolia. Antiquity 93. doi:10.15184/aqy.2019.111

Kirscher, U., Zwing, A., Alexeiev, D.V., Echtler, H.P., Bachtadse, V., 2013. Paleomagnetism of Paleozoic sedimentary rocks from the Karatau Range, Southern Kazakhstan: Multiple remagnetization events correlate with phases of deformation. Journal of Geophysical Research: Solid Earth 118, 3871-3885. doi:10.1002/jgrb.50253

Kot, M., Pavlenok, K., Krajcarz, M.T., Pavlenok, G., Shnaider, S., Khudjanazarov, M., Leloch, M., Szymczak, K., 2020. Raw material procurement as a crucial factor determining knapping technology in the Katta Sai complex of Middle Palaeolithic sites in the western Tian Shan piedmonts of Uzbekistan. Quaternary International S1040618220301580. doi:10.1016/j.quaint.2020.03.052

Krajcarz, M.T., Kot, M., Pavlenok, K., Fedorowicz, S., Krajcarz, M., Lazarev, S.Yu., Mroczek, P., Radzhabov, A., Shnaider, S., Szymanek, M., Szymczak, K., 2015. Middle Paleolithic sites of Katta Sai in western Tian Shan piedmont, Central Asiatic loess zone: Geoarchaeological investigation of the site formation and the integrity of the lithic assemblages. Quaternary International. doi:10.1016/j.quaint.2015.07.051

Kuhn, S.L., 2004. Upper Paleolithic raw material economies at Üçağızlı cave, Turkey. Journal of Anthropological Archaeology 23, 431-448. doi:10.1016/j.jaa.2004.09.001

Lawn, R., Wilshaw, T.R., 1975. Fracture of brittle solids. Cambridge University Press, Cambridge.

Lerner, H., Du, X., Costopoulos, A., Ostoja-Starzewski, M., 2007. Lithic raw material physical properties and use-wear accrual. Journal of Archaeological Science 34, 711-722.

Li, Vanwezer, N., Boivin, N., Gao, X., Ott, F., Petraglia, M., Roberts, P., 2019. Heading north: Late Pleistocene environments and human dispersals in central and eastern Asia. PLOS ONE 14, e0216433. doi:10.1371/journal.pone.0216433 
Manninen, M.A., 2016. The effect of raw material properties on flake and flake-tool dimensions: A comparison between quartz and chert. Quaternary International 424, 24-31. doi:10.1016/j.quaint.2015.12.096

Mardon, D., Kronenberg, A.K., Handin, J., Friedman, M., Russell, J.E., 1990. Mechanisms of fracture propagation in experimentally extended Sioux quartzite. Tectonophysics 182, 259-278.

Marreiros, J., Pereira, T., Iovita, R., 2020. Controlled experiments in lithic technology and function. Archaeological and Anthropological Sciences 12, 110, s12520-020-01059-5. doi:10.1007/s12520-020-01059-5

Marshall, D.B., Noma, T., Evans, A.G., 1982. A Simple Method for Determining Elastic-Modulus-toHardness Ratios using Knoop Indentation Measurements. Journal of the American Ceramic Society 65, c175-c176. doi:10.1111/j.1151-2916.1982.tb10357.x

McPherron, S.P., Abdolahzadeh, A., Archer, W., Chan, A., Djakovic, I., Dogandžić, T., Leader, G.M., Li, L., Lin, S., Magnani, M., Reeves, J., Rezek, Z., Weiss, M., 2020. Introducing platform surface interior angle (PSIA) and its role in flake formation, size and shape. PLOS ONE 15, e0241714. doi:10.1371/journal.pone.0241714

Medoev, A.G., 1964. Kamennyi vek Sary-Arka v svete noveishikh issledovanyi [Stone Age of SaryArka in the light of the latest research]. Seriya obschest.nauk 6, 55-66.

Medoev, A.G., 1982. Geohronologiya paleolita Kazahstana. Nauka, Alma Ata.

Moník, M., Hadraba, H., 2016. Mechanical characterization of raw material quality and its implication for Early Upper Palaeolithic Moravia. Quaternary International 425, 425-436. doi:10.1016/j.quaint.2016.08.042

Moník, M., Nerudová, Z., Schnabl, P., 2021. Investigation of heat-treated artefacts from Pleistocene sites. Journal of Archaeological Science: Reports 37, 102920. doi:10.1016/j.jasrep.2021.102920

Mraz, V., Fisch, M., Eren, M.I., Lovejoy, C.O., Buchanan, B., 2019. Thermal engineering of stone increased prehistoric toolmaking skill. Scientific Reports 9, 14591. doi:10.1038/s41598-01951139-3

Namen, A., Aristeidis, V., Cuthbertson, P., Iovita, R., Taimagambetov, Z., 2020a. Predvaritel'nye itogi razvedovatel'nykh rabot proekta PALAEOSILKROAD: mul'tidistsiplinarnyi podkhod $\mathrm{v}$ issledovaniyakh [Preliminary survey resuts of the PALAEOSILKROAD project: multidisciplinary approach]. In: Proceedings of the International scientific and practical conference "Great Steppe in light of archaeological and interdisciplinary research." Presented at the Margulan Readins - 2020, A. Kh. Margulan Institute of Archaeology, Almaty, pp. 60-69.

Namen, A., Cuthbertson, P., Varis, A., Schmidt, P., Taimagambetov, Z., Iovita, R., 2020b. Preliminary results of the first lithic raw material survey in the piedmont zones of Kazakhstan. SocArXiv. doi:10.31235/osf.io/uztq6

Niihara, K., Morena, R., Hasselman, D.P.H., 1982. Evaluation ofK Ic of brittle solids by the indentation method with low crack-to-indent ratios. Journal of Materials Science Letters 1, 13-16. doi:10.1007/BF00724706

Ozherelyev, D.V., Dzhasybaev, E.A., Mamirov, T.B., 2019. Pervye dannye o stratigrafii i kul'turnoǐ atribucii mnogosloĭnoĭ stojanki verhnego paleolita Rahat (Jugo-Vostochnyı̆ Kazahstan) [First data on the stratigraphy and cultural attribution of the Upper Paleolithic site of Rakhat (Southeast Kazakhstan)]. Kratkie soobshcheniya instituta arkheologii RAN Moskva 57-70.

Pavlenok, K., Kot, M., Pavlenok, G., Krajcarz, M.T., Khudjanazarov, M., Leloch, M., Szymczak, K., 2021. Middle Paleolithic technological diversity during MIS 3 in the Western Tian Shan piedmonts: Example of the Katta Sai 1 open -air loess site. Archaeological Research in Asia 100262. doi:10.1016/j.ara.2021.100262

Schmidt, P., 2020. When was silcrete heat treatment invented in South Africa? 10.

Schmidt, P., Fröhlich, F., 2011. Temperature dependent crystallographic transformations in chalcedony, $\mathrm{SiO} 2$, assessed in mid infrared spectroscopy. Spectrochimica Acta Part A: Molecular and Biomolecular Spectroscopy 78, 1476-1481. doi:10.1016/j.saa.2011.01.036

Schmidt, P., Sanchez, O.S., Kind, C.-J., 2017. Stone heat treatment in the Early Mesolithic of southwestern Germany: Interpretation and identification. PLOS ONE 12, e0188576. doi:10.1371/journal.pone.0188576

Schmidt, P., Buck, G., Berthold, C., Lauer, C., Nickel, K.G., 2019. The mechanical properties of heattreated rocks: a comparison between chert and silcrete. Archaeological and Anthropological Sciences 11, 2489-2506. doi:10.1007/s12520-018-0710-y 
Shimelmitz, R., Kuhn, S.L., Weinstein-Evron, M., 2020. The evolution of raw material procurement strategies: A view from the deep sequence of Tabun Cave, Israel. Journal of Human Evolution 143, 102787. doi:10.1016/j.jhevol.2020.102787

Shunkov, M., Anoikin, A., Taimagambetov, Z., Pavlenok, K., Kharevich, V., Kozlikin, M., Pavlenok, G., 2017. Ushbulak-1: new Initial Upper Palaeolithic evidence from Central Asia. Antiquity 91, e1. doi:10.15184/aqy.2017.208

Stoops, G., 2003. Guidlines for analysis and description of soil and regolith thin sections. Soil Science Society of America, Madison.

Taimagambetov, Zh., 1983. Shulbinskaya stoyanka [Shulbinka site]. Arkheologiya epokhi kamnya i metalla Sibiri. Novosibirsk 161-167.

Taimagambetov, Zh., 1990. Paleoliticheskaya stoyanka im. Ch. Valikhanova [The Ch. Valikhanova Paleolithic site]. Nauka KazSSR, Alma Ata.

Taimagambetov, Zh., 1997. Periods in the development of Kazak palaeolithic industries: Their chronology and correlation with the industries in contiguous territories. East and West 47, 351361.

Taimagambetov, Zh., 2009. Maibulak-First stratified Paleolithic site in Zhetysu (Kazakhstan). In: Derevianko, A.P., Shunkov, M.V. (Eds.), Drevneishie Migratsii Cheloveka v Evrazii: Materialy Mezhdunarodnogo Simpoziuma, (6-12 Sentiabria 2009 g., Makhachkala, Respublika Dagestan, Rossiia) [The Earliest Human Migrations in Eurasia: Proceedings of the International Symposium (Makhachkala, Dagestan Republic, Russia, September 6-12, 2009]. Institute of Archaeology and Ethnography Press, Novosibirsk, pp. 301-309.

Taimagambetov, Zh., Ozherelyev, D., 2008. Izuchenie stratifitsirovannoy stoyanki Maibulak v Zhetisu v 2004-2007 g. [Studies at the stratified site of Maibulak in Zhetisu, 2004-2007]. Miras 1, 7086.

Zwyns, N., Paine, C.H., Tsedendorj, B., Talamo, S., Fitzsimmons, K.E., Gantumur, A., Guunii, L., Davakhuu, O., Flas, D., Dogandžić, T., Doerschner, N., Welker, F., Gillam, J.C., Noyer, J.B., Bakhtiary, R.S., Allshouse, A.F., Smith, K.N., Khatsenovich, A.M., Rybin, E.P., Byambaa, G., Hublin, J.-J., 2019. The northern route for human dispersal in Central and Northeast Asia: New evidence from the site of Tolbor-16, Mongolia. Scientific Reports 9, 1-10. doi:10.1038/s41598019-47972-1 